\title{
CHARACTERIZATION OF DAIRY SLURRY IN SOUTHERN CHILE FARMS
}

\author{
Caracterización de purines de lecherías en el Sur de Chile
}

\author{
Francisco Salazar $^{1 *}$, Juan Carlos Dumont ${ }^{1}$, David Chadwick ${ }^{2}$, Rodolfo Saldaña ${ }^{1}$ \\ y Mabel Santana ${ }^{1}$
}

\begin{abstract}
A B S T R A C T
In this study 50 slurry samples were collected from commercial dairy farms located in the South of Chile during 1995-1997. Samples were analyzed for dry matter, $\mathrm{pH}$, organic matter, available and total macro nutrients (nitrogen, phosphorus, potassium, calcium, magnesium and sodium), available and total micronutrients (zinc, iron, manganese and copper) and total aluminum. Results showed that the dry matter content in dairy effluents was low, with $62 \%$ of the samples being $<4 \% \mathrm{DM}$. This reflected the large volumes of water that the storage received. A great variation in nutrient content was observed in the analyzed samples, probably reflecting differences in feeding regimes, use of wash water, rainfall and age of slurry at the time of sampling. In general, the concentration of macro and micronutrients was low. In the present study, the dry matter in the slurry proved to be a good indicator of some nutrients in the samples analyzed. Positive correlations $(p<0.001)$ were obtained between dry matter content and total phosphorus $\left(\mathrm{r}^{2}=89 \%\right)$, total calcium $\left(r^{2}=87 \%\right)$, total magnesium $\left(r^{2}=82 \%\right)$, available phosphorus $\left(\mathrm{r}^{2}=75 \%\right)$, ammonium nitrogen $\left(\mathrm{r}^{2}=68 \%\right)$, total potassium $\left(\mathrm{r}^{2}=64 \%\right)$, available potassium $\left(\mathrm{r}^{2}=60 \%\right)$, total nitrogen $\left(\mathrm{r}^{2}=55 \%\right)$, total zinc $\left(r^{2}=74 \%\right)$, total manganese $\left(r^{2}=64 \%\right)$ and total iron $\left(r^{2}=62 \%\right)$. Data from this study could be used as a guideline to estimate nutrient contribution from dairy slurry when applied to farmland.
\end{abstract}

Key words: nutrients, dairy effluents, cattle slurry, farm waste.

\section{R E S U M E N}

En este estudio se colectaron 50 muestras de purines de predios lecheros ubicados en el Sur de Chile (X Región). Las muestras fueron analizadas para determinar materia seca, $\mathrm{pH}$, materia orgánica, macro nutrientes totales y disponibles (nitrógeno, fósforo, potasio, calcio, magnesio y sodio). También se analizaron micronutrientes disponibles y totales (zinc, hierro, manganeso y cobre) y aluminio total. Los resultados permitieron determinar que los purines tenían un bajo contenido de materia seca, ya que $62 \%$ de las muestras tenían menos de 4\%. Esto refleja la gran cantidad de agua que reciben los pozos de almacenamiento. Se observó una gran variabilidad entre las muestras colectadas, lo que puede ser explicado por diferencias en la alimentación, uso de agua de lavado, aguas lluvia y tiempo de almacenamiento del purín. En general, la concentración de macro y micronutrientes fue baja. En el presente estudio, la materia seca del purín mostró ser un buen indicador de algunos nutrientes analizados. Correlaciones positivas ( $\mathrm{p}$ $<0,001)$ fueron obtenidas entre la materia seca y el fósforo total $\left(\mathrm{r}^{2}=89 \%\right)$, calcio total $\left(\mathrm{r}^{2}=87 \%\right)$, magnesio total $\left(\mathrm{r}^{2}=82 \%\right)$, fósforo disponible $\left(\mathrm{r}^{2}=\right.$ $75 \%)$, nitrógeno amoniacal $\left(\mathrm{r}^{2}=68 \%\right)$, potasio total $\left(\mathrm{r}^{2}=64 \%\right)$, potasio disponible $\left(\mathrm{r}^{2}=60 \%\right)$, nitrógeno total $\left(\mathrm{r}^{2}=55 \%\right)$, zinc total $\left(\mathrm{r}^{2}=74 \%\right)$, manganeso total $\left(\mathrm{r}^{2}=64 \%\right)$ y hierro total $\left(\mathrm{r}^{2}=62 \%\right)$. La información de este estudio puede ser usada como base para estimar el aporte de nutrientes de purines al ser aplicados en suelos agrícolas.

Palabras clave: nutrientes, efluentes de lechería, purines bovinos, desechos ganaderos.

\footnotetext{
${ }^{1}$ Instituto de Investigaciones Agropecuarias, Centro Regional de Investigación Remehue, Casilla 24-O, Osorno, Chile. E-mail: fsalazar@inia.cl *Autor para correspondencia.

${ }^{2}$ Institute of Grassland and Environmental Research, North Wyke, Okehampton, Devon, EX20 2SB, United Kingdom. Recibido: 29 de diciembre de 2006. Aceptado: 10 de mayo de 2006.
} 


\section{INTRODUCTION}

Milk production has increased steadily in Chile during the last years (ODEPA, 2005). This growth has resulted from intensification of production systems, which rely on a higher use of concentrates, fertilizers, forage and silage. With regard to livestock management, partial or total confinement systems have become common, resulting in a high concentration of animals generating large volumes of organic waste (slurry, dirty water and farmyard manure) in a limited land area.

The South of Chile has suitable climatic conditions and soil types for cattle production, where production systems are based principally in natural and improved pastures. The Lake Region (Región de Los Lagos) $\left(39^{\circ}\right.$ to $44^{\circ} \mathrm{S} ; 71^{\circ}$ to $73^{\circ} \mathrm{W}$ ) concentrate $56 \%$ of the national cattle herd, and produce $70 \%$ of the country's milk (ODEPA, 2005). In addition, $80 \%$ of the dairy farmers are located in this region and they own $67 \%$ of the land dedicated to dairy production, on a national basis (Anrique, 1999).

The most common confinement systems in the South of Chile are straw-based systems and housing systems (Salazar et al., 2003); the latter producing effluents and slurry. Slurry is a mixture of livestock faeces and urine, diluted with rainfall or cleaning water, and may contain a small proportion of remains of bedding, normally used in dairy cattle buildings, and feeds (Pain and Menzi, 2003). In appearance, it is a liquid material that can be pumped and that contains less than $15 \%$ of dry matter.

Slurry is an important source of organic matter and macro and micronutrients (Aguilera et al., 1995; Chambers et al., 1999; Pain, 2000). An effective management of dairy slurry should attempt to maximize economic benefits for the farmers through the implementation of adequate management and utilization practices, as well as minimizing the risks of contamination of water courses, soil and air (Wouters and Verboon, 1993; Archer and Marks, 1997). A key factor in the efficient utilization of slurry is to know its nutrient content and availability, which may be determined through an analysis of its chemical composition, as it has been reported for cattle slurry (Overcash et al., 1983; Aguilera et al., 1995; Menzi and Kessler, 1998; Demanet et al., 1999; Nicholson et al., 1999; MAFF, 2000), pig slurry and chicken manure (Nicholson et al., 1999; MAFF, 2000), fish manure (Salazar and Saldaña, 2007) and sewage sludge (Arata, 2005).

Farmers from European countries have been encouraged to analyze slurry before applying it to land, either by use of on-farm tests or by submitting samples to commercial laboratories (Van Kessel et al., 1999; Williams et al., 1999). There are also tables of compiled information about nutrient content of different types of animal slurry: dairy cattle, beef cattle, pigs, chickens, and other organic wastes (MAFF, 2000). In addition, computer programs have been developed to help estimate nutrient contribution from manures by using information from farmers (Schmitt et al., 1997; Chambers et al., 1999). This information allows farmers to make a more rational use of slurry, so that they can control the applied doses and balance them with commercial fertilizers to satisfy crop needs.

Although the use of farmyard manure and dairy slurry are a common practice among Chilean farmers, there is a lack of information about the macro and micronutrients contents of these materials. The objective of this study was to characterize chemically the slurry from dairy farms in the South of Chile, and to compare them with the values published in the literature.

\section{MATERIALS AND METHODS}

During 1995-1997 sampling was carried out on slurry lagoons or slurry concrete tanks from 50 dairy farms located in the Region de Los Lagos $\left(39^{\circ}\right.$ to $44^{\circ} \mathrm{S} ; 71^{\circ}$ to $73^{\circ} \mathrm{W}$ ) of Southern Chile. The samples were taken from dairy farms with housing and systems of slurry management and/or storage. Only large and medium size dairy farms (over 100,000 L milk $\mathrm{yr}^{-1} \mathrm{farm}^{-1}$ ) (Anrique, 1999) were chosen for this study.

Farms were visited in order to collect the samples during the housing period, between April and November. In addition, during the visit, a questionnaire was used to gather information about the management and utilization of slurry on each farm (Salazar et al., 2003).

Prior to sampling, the slurry was mixed within the storage with farm equipment, or at the sampling 
point using a manual shaker in order to collect a representative sample. A total of $2 \mathrm{~L}$ of slurry was collected from four different points (North, South, East and West) of the slurry store. The sample was stored in a plastic container and refrigerated at $<4^{\circ} \mathrm{C}$ once it reached the laboratory.

The samples were dried and grounded to a fine powder to ensure homogeneity before analysis. A fraction of each manure sample was oven dried until constant weight at $105^{\circ} \mathrm{C}$ for dry matter determination. Organic matter $(\mathrm{OM})$ was determined by loss on ignition $\left(550^{\circ} \mathrm{C}, 6 \mathrm{~h}\right)$ in a muffle furnace according to AOAC (1984). Acidity (pH) was determined by electrometric method revised by Sadzawka (1990).

Total macronutrients $\mathrm{P}, \mathrm{K}, \mathrm{Ca}, \mathrm{Na}$ and $\mathrm{Mg}$, and total micronutrients $\mathrm{Zn}, \mathrm{Fe}, \mathrm{Mn}$ and $\mathrm{Cu}$ and total $\mathrm{Al}$ were determined by acid digestion according to the methodology revised by AOAC (1984) and Sadzawka (1990). After the particulates settles out, a sample was taken for colorimetric determination of total P using a spectrophotometer (Perkin-Elmer model Lambda 3B, Phoenix, Arizona, USA). Total $\mathrm{K}$ and $\mathrm{Na}$ were determined by flame photometric method using an atomic absorption spectrophotometer (Perkin-Elmer model 1100B, Phoenix, Arizona, USA). Total $\mathrm{Ca}, \mathrm{Mg}, \mathrm{Zn}, \mathrm{Fe}, \mathrm{Mn}, \mathrm{Cu}$ and $\mathrm{Al}$ were determined by atomic absorption spectrophotometry (AAS) (Perkin-Elmer model 1100B, Phoenix, Arizona, USA).

Total nitrogen $(\mathrm{N})$ was determined on fresh manure samples by the Kjeldahl method using a block digestion system (Gerhardt model Kjeldatherm, Königswinter, Germany) and programmable distillation systems with titration (Gerhard model Vapodest 5, Königswinter, Germany) according to the methodology described by AOAC (1984). Ammonium $\mathrm{N}$ was determined by direct distillation and titrimetric using a distillation system (Gerhard model Vapodest 12, Königswinter, Germany) method revised by Sadzawka (1990). Olsen P was determined by extraction with $\mathrm{NaHCO}_{3}$ and colorimetric method (Perkin-Elmer model Lambda 3B, Phoenix, Arizona, USA) revised by Sadzawka (1990). Available $\mathrm{K}, \mathrm{Ca}, \mathrm{Na}$ and $\mathrm{Mg}$ were determined by ammonium acetate extraction and AAS as above, according to the methodology revised by Sadzawka (1990). Available $\mathrm{Cu}, \mathrm{Fe}, \mathrm{Mn}$, and $\mathrm{Zn}$ were determined by diethylenetriaminepentaacetic acid
(DTPA) micronutrient extraction method and AAS as above according to the methodology revised by Sadzawka (1990).

The chemical data gathered were analyzed statistically, media ranges being calculated for each parameter. Linear regression analyses were also carried out (GENSTAT, 1993) in order to establish relationships between slurry nutrient content and its dry matter content.

\section{RESULTS AND DISCUSSION}

The results showed that the dry matter content in slurry was generally low averaging 3.9\% (range $0.2-$ 13.7), where almost $50 \%$ of the samples did not exceed $2 \%$. These results are in agreement with the data for dairy effluents from a farm located in South Chile collected by Aguilera et al. (1995) and with that of Longhurst et al. (2000) for dairy effluents in New Zealand. The low dry matter content can be explained by the high quantity of cleaning and washing water that, directly or indirectly, enters the stores. In Argentina, a study carried out in dairy farms has shown an important contribution of clean water from the plate cooler for milk (Nosetti et al., 2002). In addition, rainfall could represent an important source of water entering the slurry store in farms located in high precipitation areas (Longhurst et al., 2000; Salazar et al., 2003). A study carried out in the South of Chile showed that a large proportion of the total volume of effluents produced came from rainfall $(46 \%)$, dirty water accounted for $29 \%$, and only $25 \%$ from cow's feces and urine (Salazar et al., 2003).

Organic matter represented a high proportion of effluent dry matter (average $68.0 \%$; range 46.6 to $85.3 \%$ ) which agrees with the results reported by Aguilera et al. (1995). It is recognized that slurry is an important source of organic matter for soils (Pain, 2000). Nevertheless, given the natural conditions in South Chile, this advantage may be reduced due to the high natural content of organic matter in soils of volcanic origin (Sadzawka and Carrasco, 1985). However, not only quantity but also the quality of organic matter is important in slurry, being balanced according to its stable and labile carbon, which helps to increase or maintain its content in the soil, optimizing the chemical and physical conditions in which slurry is utilized (Aguilera et al., 1995). 
The $\mathrm{pH}$ on manure was slightly basic, where samples averaged 7.7 (range 6.0 to 8.8 ). Laboratory experiment using high rates of manure applications on acid soil from Canada have shown an increase in soil $\mathrm{pH}$, which was attributed to buffering from bicarbonates and organic acid in cattle manure (Whalen et al., 2000). Therefore, on a long term basis the use of cattle manure in volcanic soils of South Chile, which are also acid (Sadzawka and Carrasco, 1985) could have a beneficial effect in increasing its $\mathrm{pH}$.

\section{Nutrients content}

A great variation in nutrient content was observed in the samples (Table 1), which agrees with studies carried out in other countries (Smith and Chambers, 1993; Menzi and Kessler, 1998). This variation has been associated mainly with differences in feed, type and age of animal and effluent management (Smith and Chambers, 1993; Menzi and Kessler, 1998). Moreover, it has been observed that there are seasonal variations in the composition of slurry on the same farm (Demanet et al., 1999). Another important factor to be considered is the sampling effect, given the difficulties to obtain a representative sample from the whole storage lagoon, due to the high volumes of slurry produced and the small quantity needed for laboratory analysis.

Table 1. Macronutrients content (\%) of dairy slurry determined in this study $(n=50)$, dry weight basis (\%).

Cuadro 1. Contenido de macronutrientes (\%) en purines de lechería determinados en este estudio $(n=50)$, base peso seco $(\%)$.

\begin{tabular}{lcl}
\hline Nutrient & $\begin{array}{c}\text { Average } \\
(\mathbf{\%})\end{array}$ & $\begin{array}{l}\text { Range } \\
(\%)\end{array}$ \\
\hline Total $\mathrm{N}$ & $11.20( \pm 12.89)$ & 2.20 to 64.9 \\
$\mathrm{NH}_{4}^{+}-\mathrm{N}$ & $2.90( \pm 2.476)$ & 0.60 to 14.89 \\
Total $\mathrm{P}$ & $0.91( \pm 0.573)$ & 0.40 to 4.33 \\
Olsen $\mathrm{P}$ & $0.55( \pm 0.339)$ & 0.043 to 1.69 \\
Total $\mathrm{K}$ & $4.67( \pm 3.904)$ & 0.97 to 18.77 \\
Available $\mathrm{K}$ & $4.11( \pm 2.896)$ & 0.69 to 11.91 \\
Total $\mathrm{Ca}$ & $1.93( \pm 1.018)$ & 0.82 to 7.42 \\
Available Ca & $1.33( \pm 0.996)$ & 0.137 to 4.57 \\
Total $\mathrm{Mg}$ & $0.83( \pm 0.603)$ & 0.295 to 3.98 \\
Available $\mathrm{Mg}$ & $0.56( \pm 0.385)$ & 0.085 to 1.74 \\
Total Na & $1.29( \pm 1.229)$ & 0.063 to 5.86 \\
Available $\mathrm{Na}$ & $0.97( \pm 0.760)$ & 0.030 to 3.14 \\
\hline
\end{tabular}

Values between parentheses are standard deviation.
Representative sampling is essential to obtain exact information about slurry nutrient content and, hence, optimize slurry use. However, the natural separation in slurry stores, through the deposition of solids on the bottom and the formation of a crust at the surface, makes this difficult (Lorimor et al., 2000). In addition, in earth banked lagoons it was common to find walls that had collapsed into the lagoon, creating significant contamination with soil, which may have affected the composition of the slurry.

\section{Macronutrients}

The content of macronutrients in effluents from the farms studied is shown in Table 1. In general, in a dry weight basis, $\mathrm{P}$ and $\mathrm{K}$ contents determined in the present study were similar than those reported by other authors in the literature for dairy slurry. However, $\mathrm{N}$ contents were higher in Chilean dairy slurry compared to published data (Westerman et al., 1985; MAFF, 2000). The concentration of $\mathrm{P}$ is low compared to other organic wastes, such as chicken manure, pig slurry (MAFF, 2000) or sewage sludge (Arata, 2005), that could be mainly explained for the high concentration in diets for pig and chicken production.

Most studies have focused their observations primarily on the $\mathrm{N}, \mathrm{P}$ and $\mathrm{K}$ content, and there are only a limited number of published studies that provide values for $\mathrm{Ca}, \mathrm{Mg}$ and $\mathrm{Na}$. Furthermore, in general terms (except for $\mathrm{N}$ ), they are analyzed only in relation to the total content and not with regard to the content of available nutrients. The available fraction of nutrients, especially in $\mathrm{N}$, it is of great importance because of their availability for plant use or because of the risk of losses to water, soil or air. The values obtained in this study showed that in general, an important proportion of the nutrients are soluble form, representing $94 ; 75 ; 71 ; 68$ and $61 \%$ of the total nutrient content for $\mathrm{K}, \mathrm{Na}, \mathrm{Ca}, \mathrm{Mg}$ and $\mathrm{P}$, respectively. For $\mathrm{N}$, the available fraction is mainly as ammonium nitrogen, which represented $39 \%$ of the $\mathrm{N}$ total. Previous work has shown that dairy slurry has none or low concentrations of nitrite and nitrate (Aguilera et al., 1995).

Research has shown that there is a positive relationship between the content of some nutrients and the dry matter in slurry (Piccinini and Bortone, 1991; Cumby et al., 1999; Nicholson et al., 1999). In the present study, the dry matter in the slurry 
proved to be a good indicator of some nutrients in the samples analyzed. Positive correlations $(\mathrm{p}<0.001)$ were obtained between dry matter content and total phosphorus $\left(\mathrm{r}^{2}=89 \%\right)$, total calcium $\left(\mathrm{r}^{2}=87 \%\right)$, total magnesium $\left(\mathrm{r}^{2}=82 \%\right)$, available phosphorus $\left(\mathrm{r}^{2}=75 \%\right)$, ammonium nitrogen $\left(\mathrm{r}^{2}=68 \%\right)$, total potassium $\left(\mathrm{r}^{2}=64 \%\right)$, available potassium $\left(\mathrm{r}^{2}=\right.$ $60 \%)$ and total nitrogen $\left(r^{2}=55 \%\right)$. Low correlations or none at all were obtained with available magnesium $\left(\mathrm{r}^{2}=46 \%\right)$, available sodium $\left(\mathrm{r}^{2}=36 \%\right)$, available calcium $\left(\mathrm{r}^{2}=30 \%\right)$ and total sodium $\left(\mathrm{r}^{2}=\right.$ $28 \%$ ), respectively. Similar correlations have been reported previously by Piccinini and Bortone (1991) for total $\mathrm{N}$, total $\mathrm{P}$ and $\mathrm{NH}_{4}^{+}-\mathrm{N}$ in slurry and by Cumby et al. (1999) for total P, total N, total K and $\mathrm{NH}_{4}^{+}-\mathrm{N}$ in dirty water (from washing parlor equipment and floor) from dairy farms.

The fact that some nutrients are positively correlated with dry matter in slurry seems to indicate that these elements are mainly associated with their solid fraction and not with the liquid fraction. Data reported by Safley et al. (1984) for dairy cow showed that most of the P (95\%), Ca (97\%), and $\mathrm{Mg}(78 \%)$ were in faeces compared to urine. In addition, a study carried out by Aguilera et al. (1995) concluded that most of the P was in the solid fraction compared to the liquid fraction after dairy slurry separation.

In order to reduce the time spent analyzing dairy slurry, field equipment have been developed taking into consideration the relationship between dry matter content in slurry and some nutrients (Van Kessel et al., 1999; Williams et al., 1999). This equipment, such as hydrometers, makes it possible to rapidly predict the nitrogen or phosphorus content and is a technique that can easily be used by farmers because of its practicality and low cost. In addition, tables with standard data about the content of nutrients in slurry are also useful when laboratory analyses are not available (Chambers et al., 1999; Lorimor et al., 2000). However, the use of these values should not replace a proper analysis, since the nutrients content may vary considerably between dairy farms (Hart et al., 1997; Lorimor et al., 2000) and between different seasons on the same farm (Demanet et al., 1999).

\section{Micronutrients}

Like macronutrients, the micronutrients analyzed ( $\mathrm{Zn}, \mathrm{Fe}, \mathrm{Mn}, \mathrm{Cu}, \mathrm{Al}$ ) showed great variation in their concentrations (Table 2). This variation is common for most of the organic wastes (Overcash et al., 1983; Nicholson et al., 1999; Salazar and Saldaña, 2007), being most likely due to the presence or not of mineral supplements feed to dairy cattle (Nicholson et al., 1999; Li et al., 2005).

The available nutrients contents were low for all the elements analyzed, which, when expressed as a percent of the total micronutrient analyzed, were $28 ; 16 ; 13$ and $9 \%$ for $\mathrm{Mn}, \mathrm{Fe}, \mathrm{Cu}$ and $\mathrm{Zn}$, respectively.

Table 2. Micronutrients content of dairy slurry determined in this study, compared to published data, dry weight basis $\left(\mathrm{mg} \mathrm{kg}^{-1}\right)$.

Cuadro 2. Contenido de micronutrientes en purines de lechería determinados en este estudio, comparados con datos publicados en la literatura, base peso seco $\left(\mathrm{mg} \mathrm{kg}^{-1}\right)$.

\begin{tabular}{|c|c|c|c|c|c|}
\hline \multirow[t]{2}{*}{ Nutrient } & \multicolumn{2}{|c|}{ This study } & \multirow{2}{*}{$\begin{array}{c}\text { Menzi and } \\
\text { Kessler } \\
(1998)\end{array}$} & \multirow{2}{*}{$\begin{array}{c}\text { Nicholson } \\
\text { et al. } \\
(1999)\end{array}$} & \multirow{2}{*}{$\begin{array}{c}\text { Overcash } \\
\text { et al. } \\
(1983)\end{array}$} \\
\hline & Average & Range & & & \\
\hline Total $\mathrm{Cu}$ & $158( \pm 274.1)$ & 13.8 to 1,498 & 19.1 & 62 & 31 \\
\hline Available $\mathrm{Cu}$ & $42.6( \pm 57.11)$ & 3.20 to 281 & n.d. & n.d. & n.d. \\
\hline Total Fe & $5,232( \pm 3,716.9)$ & 106 to 16,679 & n.d. & n.d. & 1,170 \\
\hline Available Fe & $1,968( \pm 1,455.0)$ & 164 to 6,178 & n.d. & n.d. & n.d. \\
\hline Total Mn & $680( \pm 556.9)$ & 241 to 3,138 & n.d. & n.d. & 145 \\
\hline Available Mn & $391( \pm 343.6)$ & 68.5 to 1,430 & n.d. & n.d. & n.d. \\
\hline Total Zn & $173( \pm 144.1)$ & 57.7 to 1,049 & 123 & 209 & 210 \\
\hline Available Zn & $35.5( \pm 33.35)$ & 4.77 to 157 & n.d. & n.d. & n.d. \\
\hline Total Al & $11,111( \pm 13,128.2)$ & 1,858 to 71,666 & n.d. & n.d. & 1,050 \\
\hline
\end{tabular}

Values between parenthesis are standard deviation.

Total $\mathrm{Cu}, \mathrm{Fe}, \mathrm{Mn}$ and $\mathrm{Zn}$, sample number = 50; total $\mathrm{Al}$ and available $\mathrm{Cu}, \mathrm{Fe}, \mathrm{Mn}$ and $\mathrm{Zn}$, sample number $=30$ n.d.= not determined in this study. 
High correlations $(\mathrm{p}<0.001)$ were observed between dry matter content of the effluent and total zinc $\left(r^{2}=74 \%\right)$, total manganese $\left(r^{2}=64 \%\right)$ and total iron $\left(\mathrm{r}^{2}=62 \%\right)$ respectively. Low correlation or none at all were determined for available manganese $\left(r^{2}=50 \%\right)$ and total aluminum $\left(r^{2}=25 \%\right)$, available iron $\left(\mathrm{r}^{2}=23 \%\right)$, available zinc $\left(\mathrm{r}^{2}=9 \%\right)$, available copper $\left(r^{2}=2 \%\right)$ and total copper $\left(r^{2}=1 \%\right)$.

Most of the micronutrients analyzed $(\mathrm{Cu}, \mathrm{Fe}, \mathrm{Mn}$ and $\mathrm{Al}$ ) showed higher concentrations than the values reported for dairy cattle slurry in different studies carried out in other countries (Table 2). Only $\mathrm{Zn}$ had similar concentrations (Overcash et al., 1983; Chambers et al., 1998; Menzi and Kessler, 1998; Nicholson et al., 1999). Aluminum and iron concentrations were particularly high in dairy farm effluents in the South of Chile, with values five to eight times higher than those reported for dairy farm effluents in the USA (Overcash et al., 1983). A similar or high level of $\mathrm{Al}$ has been reported by Salazar and Saldaña (2007) for fish manure collected from fish farms located in lakes or sea in South Chile. The values observed of micronutrients in Chilean dairy slurry may be associated with high levels of microelements in feeds and forage in dairy systems in the South of Chile. A survey carried out in Wisconsin dairy feeds found high levels of metals $(\mathrm{Zn}, \mathrm{Cu}, \mathrm{Cr}, \mathrm{As}, \mathrm{Cd}$ and $\mathrm{Pb}$ ) in purchased feed, particular mineral supplements, and to a lesser extent corn or soybean based concentrates (Li et al., 2005).

It has been observed that there is a close relationship between the levels of microelements in cattle feed, the conversion efficiency of animals and their presence in slurry (Menzi and Kessler, 1998; Nicholson et al., 1999). A significant proportion of the samples (ca. 50\%) were collected from earthbank lagoons, where soil contamination can modify the composition of dairy slurry stored in them. Furthermore, on some farms, soil was used as bedding for the animals, resulting in the material being taken to the slurry lagoon along with manure, urine and wastewater. Another important aspect to consider is the chemical characteristic of soils in the South of Chile, which present high aluminum content due to their volcanic origin (Bernier, 1988). In a study carried out in the South of Chile, high levels of this element were found in the blood of young bulls grazing on soils with high $\mathrm{Al}$ content (Alfaro, 1995).
In the literature, the values given for micronutrients do not usually consider their available fraction, only the total content being analyzed (Menzi and Kessler, 1998). The data obtained in the present study showed that $58 \%$ of $\mathrm{Mn}, 38 \%$ of $\mathrm{Fe}, 32 \%$ of $\mathrm{Cu}$ and $22 \%$ of $\mathrm{Zn}$ were soluble compared to total metal content. This fact may have important implications from an agronomical point of view, because of its direct relationship with availability for crops and grasslands and the risk of losses into the environment. In addition, it is important to be aware that metal addition to soil could be highly depending on application rates of slurry, especially in areas where animal manures have been applied for many years and if applications are expected to continue, it is likely that soil metal accumulation rates will be at least greater (Nicholson et al., 1999) and could become more available.

The dry matter content in dairy effluents proved to be a good parameter to relate to the total content of $\mathrm{Zn}, \mathrm{Mn}$ and $\mathrm{Fe}$ (based on fresh weight). Low correlations or none at all were established for the other elements. Nicholson et al. (1999) established that in dairy effluents there were positive correlations between the dry matter content in the effluent and $\mathrm{Zn}$; however, these authors found low correlations with $\mathrm{Cu}$, which contrasts with the results of this study.

\section{CONCLUSIONS}

Dairy slurry samples had low dry matter contents $(3.9 \%)$ and high organic matter contents $(68 \%)$. In general, the concentration of macro and micronutrients was low compared to other animal manures. In the present study, the dry matter in the slurry proved to be a good indicator of some nutrients in the samples analyzed. Positive correlations $(p<0.001)$ were obtained between dry matter content and total phosphorus $\left(\mathrm{r}^{2}=89 \%\right)$, total calcium $\left(r^{2}=87 \%\right)$, total magnesium $\left(r^{2}=82 \%\right)$, available phosphorus $\left(\mathrm{r}^{2}=75 \%\right)$, ammonium nitrogen $\left(r^{2}=68 \%\right)$, total potassium $\left(r^{2}=64 \%\right)$, available potassium $\left(r^{2}=60 \%\right)$, total nitrogen $\left(r^{2}=55 \%\right)$, total zinc $\left(r^{2}=74 \%\right)$, total manganese $\left(\mathrm{r}^{2}=64 \%\right)$ and total iron $\left(\mathrm{r}^{2}=62 \%\right)$.

Data and relationship from this study could be used as a baseline to estimate nutrient contribution from dairy slurry when applied to farmland and laboratory analyses are not available. In addition, 
good correlation between slurry dry matter contents and nutrients could be used to calibrate slurry onfarm analysis test for Chilean dairy farms. This would allow matching nutrients requirements for crops and therefore to implement Good Management Practices on Chilean dairy farms.

\section{ACKNOWLEDGEMENTS}

To Mrs. Paulina Zuñiga for her technical assistance in the revision of this paper and to the Chilean farmers who allowed us to collect slurry samples in their farms.

\section{CITED LITERATURE}

Aguilera, S., G. Borie, P. Peirano, M. Mora, y R. Demanet. 1995. Caracterización de purines para su potencial uso como fertilizante y mejorador de suelos. Agric. Téc. (Chile) 55:251-256.

Alfaro, M. 1995. Estudio de las relaciones existentes en el ciclo suelo planta animal de un Andisol acidificado de la zona Sur de Chile. Tesis Ingeniero Agrónomo. 170 p. Universidad de La Frontera, Facultad de Ciencias Agropecuarias y Forestales, Temuco, Chile. Anrique, R. 1999. Caracterización del Chile lechero. p. 140-157. In R. Anrique et al. (eds.). Competitividad de la producción lechera nacional. Vol. 1. Universidad Austral de Chile, Facultad de Ciencias Agrarias, Valdivia, Chile.

AOAC. 1984. Official methods of analysis. Association of Official Agricultural Chemist (AOAC), 14th ed. 1141 p. William, S. (ed.). Association of Official Analytical Chemists, Washington DC, USA.

Arata, P. 2005. Evaluación de la calidad del lodo en la Región Metropolitana y su uso agrícola. p. 31-38. In S. González, F. Tapia and R. Ruíz (eds.). Seminario uso benéfico de lodos, proyecto valorización de lodos. Serie Actas $\mathrm{N}^{\circ}$ 27. Instituto de Investigaciones Agropecuarias, Santiago, Chile.

Archer, J.R., and M.J. Marks. 1997. Control of nutrient losses to water from agriculture in Europe. 31 p. Proceedings $\mathrm{N}^{\circ} 405$. The International Fertiliser Society, London, UK.

Bernier, R. 1988. Fertilización de praderas. p. 179-206. In I. Ruiz (ed.). Praderas para Chile. Instituto de Investigaciones Agropecuarias, Santiago, Chile.

Chambers, B., F. Nicholson, D. Soloman, and R. Unwin. 1998. Heavy metal loadings from animal manures to agricultural land in England and Wales. p. 495-506. In J. Martínez and M. Maudet (eds.). Proceedings of the FAO-Network on Recycling Agricultural, Municipal and Industrial Residues in Agriculture (RAMIRAN) Conference, Rennes, France. 28-29 May 1998. FAO y CEMAGREF, Rennes, France.
Chambers, B., N. Nicholson, K. Smith, B. Pain, T. Cumby, and I. Scotford. 1999. Managing livestock manures: Making better use of livestock manures on arable land. Booklet 1.25 p. Ministry of Agriculture, London, UK.

Cumby, T.R., A. Brewer, and S. Dimmock. 1999. Dirty water from dairy farms. I. Biochemical characteristics. Bioresour. Technol. 67:155-160.

Demanet, R., M. Aguilera, y M. Mora. 1999. Efecto de la aplicación de purines sobre el sistema suelo-planta. Frontera Agrícola No 5 p. 87-94.

GENSTAT. 1993. GENSTAT 5. Release 3. Reference Manual. Oxford Univesity Press, Oxford, UK.

Hart, J., E. Marx, N. Christensen, and J. Moore. 1997. Nutrient management strategies. J. Dairy Sci. 80:2659-2666.

Li, Y., D.F. Mc Crory, J.M. Powel, H. Saam, and D. Jackson-Smith. 2005. A survey of selected heavy metal concentrations in Wisconsin dairy feeds. J. Dairy Sci. 88:2911-2922.

Longhurst, R., A. Roberts, and M. O'Connor. 2000. Farm dairy effluent: A review of published data on chemical and physical characteristics in New Zealand. N.Z. J. Agric. Res. 43:7-14.

Lorimor, J., W. Powers, and A. Sutton. 2000. Manure characteristics. MWPS-18. 23 p. Manure Management System Series. Mid West Plan Service, Iowa, USA.

MAFF. 2000. Fertiliser recommendations handbook for agriculture and horticulture crops (RB209). $7^{\text {th }}$ ed. 175 p. Ministry of Agriculture, Fisheries and Food (MAFF). The Stationery Office, London, UK.

Menzi, H., and J. Kessler. 1998. Heavy metal content of manures in Switzerland. p. 495-506. In J. Martínez and M. Maudet (eds.). Proceedings of the FAONetwork on Recycling Agricultural, Municipal and Industrial Residues in Agriculture (RAMIRAN) Conference, Rennes, France. 28-29 May 1998. FAO y CEMAGREF, Rennes, France. 
Nicholson, F., B. Chambers, J. Williams, and R. Unwin. 1999. Heavy metal contents of livestock feeds and animal manures in England and Wales. Bioresour. Technol. 70:23-31.

Nosetti, L., M. A. Herrero, M. Pol, V. Maldonado, M. S. Iramain, and M. Flores. 2002. Cuantificación y caracterización de agua y efluentes de establecimientos lecheros. I. Demanda de agua y manejo de efluentes. Inv. Vet. 4:37-43.

ODEPA. 2005. Boletín de la leche. 2004. 51 p. Ministerio de Agricultura, Oficina de Estudios y Políticas Agrarias (ODEPA), Santiago, Chile.

Overcash, M., F. Humenik, and J. Miner. 1983. Livestock waste management. 260 p. Volume I. CRC Press, Florida, USA.

Pain, B. 2000. Control and utilization of livestock manures. p. 343-364. 3rd ed. In A. Hopkins (ed.). Grass: its production and utilization. British Grassland Society, Blackwell Science Ltd., Oxford, UK.

Pain, B., and H. Menzi. 2003. Glossary of terms on livestock manure management 2003. 59 p. Recycling agricultural, municipal and industrial residues in agriculture network. Swiss College of Agriculture, Zollikofen, Switzerland.

Piccinini, S., and G. Bortone. 1991. The fertilizer value of agricultural manure: simple rapid methods of assessment. J. Agr. Eng. Res. 49:197-208.

Sadzawka, A. 1990. Métodos de análisis de suelos. Serie La Platina $\mathrm{N}^{\mathrm{o}} 16.127$ p. Instituto de Investigaciones Agropecuarias, Santiago, Chile.

Sadzawka, A., and M. Carrasco. 1985. Química de los suelos volcánicos. p. 337-490. In J. Tosso (ed.). Suelos volcánicos de Chile. Instituto de Investigaciones Agropecuarias, Santiago, Chile.

Safley, L.M., J.C. Barker, and P.W. Westerman. 1984. Characteristic of fresh dairy manure. Trans. ASAE 27:1150-1153.

Salazar, F.J., J.C. Dumont, M.A. Santana, B.F. Pain, D.R. Chadwick, and E. Owen. 2003. Prospección del manejo y utilización de purines de lecherías en el Sur de Chile. Arch. Med. Vet. 35:215-225.
Salazar, F.J. and R. Saldaña. 2007. Characterization of manures from fish cage farming in Chile. Bioresour. Technol. Available at: http://www.elsevier.com/wps/ find/journaldescription.cws home/405854/ description\#description Accessed March, 2007.

Schmitt, M., R. Levins, and D. Richarson. 1997. Manure application planner (MAP): Software for environmental and economical nutrient planning. J. Prod. Agric. 10:441-446.

Smith, K., and B. Chambers. 1993. Utilizing the nitrogen content of organic manures on farms-problems and practical solutions. Soil Use Manage. 9:105-112.

Whalen, J.K., C. Chang, G.W. Clayton, and J.P. Carefoot. 2000. Cattle manure amendements can increase the pH of acidic soils. Soil Sci. Soc. Am. J. 64:962-966.

Westerman, P.W., L.M. (Jr). Safley, J.C. Barker, and G.M. Chescheir. 1985. Available nutrients in livestock waste. p. 295-304. In Agricultural waste utilization and management. Proceedings of the Fifth International Symposium on Agricultural Wastes, Chicago, Illinois, USA. December 16-17 1985. American Society of Agricultural Engineers, Chicago, Illinois, USA.

Wouters, A., and M. Verboon. 1993. Handling of slurry in relation to the environment on dairy farms in the Netherlands. p. 85-96. In A. Hopkins and D. Younie (eds.). Forward with grass into Europe. Proceeding of the BGS Winter Meeting N²7, Great Malvern. November 16-17. British Grassland Society, Great Malvern, Reading, UK.

Van Kessel, J.S., R.B. Thompson, and J.B. Reeves. 1999. Rapid on-farm analysis of manure nutrients using quick tests. J. Prod. Agr. 12: 215-224.

Williams, J.R., C.L. Hurst, B.J. Chambers, S. Brookman, and D. Chadwick. 1999. Rapid methods for the analysis of readily available nitrogen in manure. $p$. 171-172. In A.J. Corrall (ed.). Accounting for nutrients: a challenge for grassland farmers in the $21 \mathrm{st}$ Century. Proceeding of the BGS Ocassional Symposium No 33. November 22-23. British Grassland Society, Great Malvern, Reading, UK. 